\title{
Students Attitude Towards LGBTQ; the Future Counselor Challenges
}

\author{
Zadrian Ardi $^{1}$, Frischa Meivilona Yendi $^{2} \&$ Ifdil Ifdil $^{3}$ \\ Universitas Negeri Padang \\ Đe-mail: zadrian@konselor.org
}

\begin{abstract}
Abstrak
Disorientations of sexual behavior is an individual condition that does not appear in uni-factor, in other words, the condition was developed as a result of various factors in the individual's life span. Sexual orientation deviation that are currently popular with the LGBTQ (Lesbian, Gay, Bisexual, Transgender and Queer) is a phenomenon that always comes in every community in recent years and this community rights and loudly voiced by some developed countries. This causes problems and polemics in the life dimensions, absolutely in the client's life. The counselor as a social worker who is in direct contact with this condition should have concrete steps in handling, good preventive measures and curative measures through counseling and psychotherapy. The counseling psychotherapys' and point of views in this problem is one of the key points that can be used as a preliminary approach. In addition, concrete steps in counseling services are expected to be a way out for clients to reach a happines lifes, independent and selfcontrol.
\end{abstract}

Kata Kunci: LGBT, Counseling approach, Students attitude

Copyright (C) 2017 IICET (Indonesia) - All Rights Reserved

Indonesian Institute for Counseling, Education and Therapy (IICET)

\section{PENDAHULUAN}

Access to information is so easy to be one factor in the speed of crossing cultures of different regions and even countries, which in turn increases the chances for behavioral patterns are different in society. (Pontororing, 2012). This is no exception occurred in Indonesia with the culture, demography, education level and socioeconomic status are very diverse. The difference becomes natural with a fairly rapid population growth up to now number about 220 million and about 6,000 islands scattered in the diversity of languages as many as 700 types of local language (Boellstorff, 2004).

Various aspects of social problems may emerge as a compensation of these developments. Among the problems that recently received special attention and controversy among practitioners, academics and the public at large is the problem of deviant sexual orientation, where the condition is not got agreement from the wider community, particularly Indonesia (Siregar, 2013). Kemenyimpangan this is basically not a new thing in the reality of social life, but the problem re-surfaced and invite various reactions after same-sex marriage endorsement by the United States Supreme Court (BBC News, 2015). The deviant sexual orientation is explicitly categorized in Lesbian, Gay, Bisexual, Transgender and Queer (LGBTQ).

When viewed from the LGBTQ population that requires attention and treatment can be seen from the exposure data indicate that there are at least 2\%-13\% of the world population is an individual who has a sexual orientation, and $60 \%$ of them are young people (Dank, Lachman, Zweig, \& Yahner, 2014; Rhomadona, 2012; Sumadi \& Revelation, 2013). Indonesia's territory itself, various research in 2014 estimated that people with LGBTQ is as much as $1 \%$ of the total population of the Indonesian people and it is estimated this figure will continue to grow each year (Azmi, 2015). In addition to Indonesia's population who 
live in his own country, people with LGBTQ sexual orientation experienced by Indonesian workers abroad with a number of people with quite a lot. In 2013 found $84.45 \%$ of Indonesian workers who work at Hongkong is a lesbian and does not hesitate to show that sexual orientation in public (Afifah, 2015). When viewed from the standpoint of sociology and social pathologies, homosexuals may be defined as the tendency of a person who prefers a man with sex sala as a partner in meeting the needs of partners in the libido and sexual relations (Fifi, 2015). However, there were no single factor that causes a person infected with the LGBTQ conditions, because the determining factors of LGBTQ behavior is a combination of various factors; including the factor of biological, psychological, and social, in addition to the influence of environmental adverse effects on normal sexual maturity and influence parenting parents (Sumadi \& Revelation, 2013).

Deviant sexual tendencies concern by this special population carries a fairly specific movement in order to demonstrate their existence. This is manifested in the form of the advent of magazines, websites and other technology-based program that shows the exclusivity of their population (Juditha, 2014). These opportunities are well received by the analysis that targeting specific audience and specifically, the media disseminates the information and media were free to express themselves will survive although there will be shocks from other parties. With the media, LGBTQ minorities would show increasingly strong position and reinforcement to their audience (Juditha, 2014).

In addition, the emerging reality on the ground is often found in a campus environment some students who look masculine man wearing jeans, shirt or T-shirt, sports shoes and a short haircut exactly like most college students (Saputra, 2015). This condition is clearly one indicator of which is the benchmark of selfexpression for minorities, irrespective of stigma and prejudice against individuals who express themselves thus. Or for cases of bisexual men, the majority of infected are men who have even been married and has a child has multiple sexual orientas (Siregar, 2013). The condition is clearly a phenomenon that should receive special attention from various parties. Other findings also pointed to the fact that the majority of people with LGBTQ a young child with a lifespan of between 17-22 years with a status as a student and the student (Arsita, 2014). Guided by the findings in the field and the exposure of the facts research results regarding the condition of LGBTQ counselor as a profession recognized by the government in handling the client is expected to become party

\section{Public rejection over LGBTQ victims}

Society perceives the problem condition LGBTQ with various viewpoints, most assume that the deviation of sexual orientation is a violation of the norms that apply generally and others consider that this trend is a lifestyle (Rhomadona, 2012) so that the controversy still emerging regarding the ratification of same-sex marriage the. One of the LGBTQ realities that often arise in people's lives is the presence of a layer of a sissy. Pansy can be defined as a term for a man who became a woman, both in behavior and appearance (Boellstorff, 2004). In fact, the existence of pansy still raises various pros and cons in the community. In addition, a variety of reactions to the emergence of homosexuals is due to the social fabric of Indonesian society teach values heteronormatif which has the assumption that heterosexuality is the only norm that is considered normal and appropriate, so that a relationship / value sexuality is considered normal if complementary between between men and women (Mariani, 2013; Yuwono, 2013). So with the presence of several individuals who deviate from normal Autran society will invite conflict, humiliation, stigma and prejudice both in the family and society (Mariani, 2013; Saputra, 2015). This of course will make the people closest to the individual in question will get away with way alienate or exclude the existence of the minority (Mariani, 2013).

There are various causes of society's view of people with LGBTQ minorities. Conditions that actually makes people with these conditions remain in a relationship similar to the way clandestinely (Siregar, 2013) or by creating an exclusive community. Exclusive groups was hosted online or organization that has been structured. Networking members with online media is done in a variety of social media, one of them is a facebook group (Arsita, 2014). In addition, the Association also accommodated by the construction of community websites, some of which are Gaya Nusantara, Prewakos, Savy Amira and so forth (Saputra, 2015). The more organized groups are also made exclusively by utilizing various major centers such as malls, karaoke, cinema and so on as a gathering place (Arsita, 2014). 
Seeing this reality, it is a simultaneous impact on the perception of the general public about the outlook and the handling of the people with the LGBTQ. Of course this will bring a wide range of impacts and risks for people with LGBTQ (Vitasandy 2010) in terms of both psychological and physiological. Risk LGBTQ person with the condition is low self-esteem and self-concept. View factor against people with LGBTQ communities will form less significant feelings of the individual self (Vitasandy, 2010). If that continues to be experienced by the individual, then it will have an impact in the form of stress and depression. Risks of the treatment and conditions of minority communities will bring people in distress and feelings of discrimination that led to depression (Gattis, Woodford, \& Han, 2014).

In addition to the problem of depression and stress, a person's sexual orientation disorder will have a risk of reproductive health problems is greater. Based on the results of research in one of the cities in Indonesia says that more than $50 \%$ of people with lesbians who have adequate knowledge about the risk of having a type (Rhomadona, 2012), this will certainly open up opportunities spread of sexually transmitted diseases are higher among people with LGBTQ. Individuals who suffer sexual orientation in the form of LGBTQ have a higher risk of sexual violence compared with individuals who have a tendency heterosexual (Gattis et al., 2014; Richardson, Armstrong, Hines, and Palm Reed, 2015). This happens because when someone LGBTQ people with sexually abused, then the victim would not report it because ultimately the victim will still be blamed for conditions that happen to him (Richardson et al., 2015). Various forms of sexual violence can be experienced by people with LGBTQ, including physical violence in sexual relations, psychological violence, cyber violence and coercion to sexual intercourse, even most victims are young children and adolescents (Dank et al., 2014).

When viewed from a gender, more women experienced sexual violence compared to people with LGBTQ men (Dank et al., 2014), which in addition to being sexually assaulted women who have homosexual tendencies also lead unhealthy lifestyles including smoking 4.9 times more many heterosexual women, and 10.7 times more to drink alcohol than heterosexual women

\section{Methodology}

This research is descriptive (Lodico, 2006; Singh, 2007) which aims to how the image of the tendency of the attitude of students in the city of Padang on the phenomenon of LGBT besides also conducted a further analysis by considering the data group sex, ethnicity, figure parenting, etc. Consideration of data collection is based on the type of college in Padang, consisting of State Universities and Private Universities in the city of Padang random / random. The number of samples taken by the representation of the type of universities is as much as 213 respondents. The data collection is done by using an instrument which is an adaptation of the scale "Worthen's (2012) Attitudes toward LGBT People Survey"

\section{Result}

Some results that answer some of research's questions as we can see from the table.

\begin{tabular}{clcc}
\hline No & Category & f & \% \\
\hline $\mathbf{1}$ & Very High & 1 & 0,47 \\
$\mathbf{2}$ & High & 0 & 0,00 \\
$\mathbf{3}$ & Moderate & 7 & 3,30 \\
$\mathbf{4}$ & Low & 178 & 83,96 \\
$\mathbf{5}$ & Very Low & 26 & 12,26 \\
& Total & 212 & 100 \\
\hline
\end{tabular}

Based on exposure data is $83.96 \%$ of the students in the city of Padang has a low stance on LGBT phenomenon, it is marked out of 212 samples, 178 samples are in the low category. By contrast, 1 students who sampled the attitude was very high against the LGBT phenomenon. The results of the research will explain about how the image of the tendency of student attitudes toward LGBT phenomenon when viewed from the phenomenon of lesbian, gay, bisexual, and transgender.

However, when seen in detail, there are significant differences in the views from the transgender phenomenon. 
Jurnal Konseling dan Pendidikan

http://jurnal.konselingindonesia.com

Vol. 5 No. 2, 2017. hlm. 74-79

\begin{tabular}{llcc}
\hline No & Category & f & \% \\
\hline $\mathbf{1}$ & Very High & 3 & 1,42 \\
$\mathbf{2}$ & High & 34 & 16,04 \\
$\mathbf{3}$ & Moderate & 155 & 73,11 \\
$\mathbf{4}$ & Low & 19 & 8,96 \\
$\mathbf{5}$ & Very Low & 1 & 0,47 \\
Total & & 212 & 100 \\
\hline
\end{tabular}

Note that $73.11 \%$ of the students in the city of Padang has a good enough attitude to the phenomenon of bisexuality, it is marked out of 212 samples, 155 samples are in good enough category. By contrast, 1 students $(0.47 \%)$ that the sample has a very low attitude towards transgender phenomenon.

\section{Discussion \\ The Counseling Challenges in the Future}

Handling conditions LGBTQ clients who have categorized in special populations (Allan, Tebbe, Duffy, \& Autin, 2015). This is because not all individuals will feel and experience this condition, and just because someone factors change sexual orientation. Various problems experienced by people with LGBTQ require special handling by the counselor, especially it concerns the conditions of life of clients, especially in the form of marginalization, interruption in career, community norms and religious beliefs (Allan et al., 2015; Gattis et al., 2014) Handling counseling to clients who develop LGBTQ be very crucial because more than $60 \%$ of people with a tendency sexual orientation feel safe and comfortable when going to school, and many of them had symptoms of depression, self-esteem is low, irregular school attendance and learning outcomes is low (Dank et al., 2014). In addition, some research suggests that the emotional pain experienced by patients LGBTQ be one of the causes of a person's sexual orientation has a tendency to deviate (Sumadi \& Revelation, 2013) so that the condition of the wound needs to be a counselor. Another condition that must be a concern for counselors is the condition in people with LGBTQ order motive that leads to a desire to again have a heterosexual orientation or become normal in view of the public (Saputra, 2015). Given in some developed countries in the world have to categorize the behavior of sexual orientation LGBTQ no longer a symptom of irregularities (has been declared out of DSM IV) and not listed anymore in the medical report of WHO (World Health organizaton, 2001) then this means that globally, not many of which will examine the handling or eradicate this behavior. But this certainly does not apply in Indonesian culture. Indigenous eastern of Indonesia considers that LGBTQ behavior is something that is considered "normal" (Azmi, 2015) and requires special handling. Of course counselor in Indonesia, and is supposed to be wise to the norm must take a role in this effort. The emergence of the phenomenon of LGBTQ which is now starting to look to the surface like a picture of an iceberg that still require effort for more in-depth search (Azmi, 2015) one of them carried out by the counselor. Counselors as educators (Ministry of National Education, 2003) essentially has the responsibility of maintaining the principles of national education in each ministry, one of which is in the handling of sexual orientation deviant behavior. Moreover, education is one of them based on value investment-savvy characters (Marjohan, 2012) are also not in accordance with the conditions LGBTQ.

\section{Handling the Situation; healing and preventive}

Many factors cause someone to change sexual orientation. These factors include the role of socialization and spiritual values that are low in a family environment, in addition to the factors of relationships and social interaction of peers who first have a tendency LGBTQ the (Sumadi \& Revelation, 2013) coupled with the fact that people with LGBTQ generally make contact with clandestinely (Siregar, 2013). Previous studies revealed that there was a lot of stigma and prejudice against the existence of LGBTQ minorities so that it will affect the way they behave (Worthen, 2012). Furthermore, the condition of lack of adequate information of these bring a certain stigma and fear conditions such as homophobia, bi-phobia and trans-phobia in society (Worthen, 2012). Conditions taboo and this ignorance is one reason why it is difficult to take preventive measures someone mired in deviant sexual orientation or behavior pengentasannya step. Various preventive measures (preventive) to do so as an individual does not fall within the LGBTQ behavior. Organizing counseling services with a grounding terciptaya everyday life is one step that can be done (Marjohan, 2012), the service is carried out in the realm of development of individual life goals, increase self competence, and terimplementasikannya moral values in self-reliance and self-control. Another step that can 
be done to prevent the transmission of LGBTQ condition is the increased role of the family in maintaining the reliability of the functions of morality in children. This is important because if the conditions are not conducive families (poor communication, lack of parental control, lack of cultivation of moral values) will have an impact on the ease of people (children) fall into the condition of LGBTQ (Sumadi \& Revelation, 2013). Next is the government's role in preventing the emergence of cases in the LGBTQ community. The government basically need to make efforts to maintain the noble nation cultures through various regulations and agenda to prevent homosexual behavior (Afifah, 2015). In addition to preventive measures, reduction LGBTQ behavior is also required for individuals who already have a deviant sexual orientation question. Counseling services to all areas of development (Ardi, 2012) is an effort to eradicate this behavior. Fields that interact directly with LGBTQ condition are private fields, where all the dimensions of individual personality merupakah study areas of drawing this overall process of counseling services. In addition, a variety of approaches to counseling may be applied to alleviate this problem, such as by the application of the six basic continuum of counseling transgender (Azmi, 2015). The practice of psychotherapy is also one way to alle viate this problem that can be performed by the counselor. Services using hypnotherapy approach will help clients in absorbing yourself, know yourself and the environment and values didalaminya during this (Kahija, 2007). By studying the client, the counselor may assess measures precise handling and efficient. Another possible approach is to Art Therapy. In some cases, clients may not be disclosed to clients and less able to do good communication with regard to cases that experienced, so it requires a deepening of the media to perform such conditions (Rubin, 2010). With a significant result, this approach may be one alternative handling conditions on self LGBTQ clients who may be less able to reveal the problem. Knowledge and deepening of the beginning of the client's condition with a homosexual orientation can be done by analysis of images through this therapy (Davido, 2012), ie, when one child (or may also be true for adults) are likely to directly draw people with the same sex although asked to free drawing.

\section{DAFTAR RUJUKAN}

Afifah, N. (2015). Peran Pemerintah Indonesia dalam Mengatasi Perilaku Lesbian Tenaga Kerja Wanita di Hongkong (2007-2009). Jom FISIP, 1(1), 1-11. http://doi.org/10.1017/CBO9781107415324.004

Allan, B. A., Tebbe, E. A., Duffy, R. D., \& Autin, K. L. (2015). Living a Calling, Life Satisfaction, and Workplace Climate among a Lesbian, Gay, and Bisexual Population. Career Development Quarterly, 63(4), 306-319. http://doi.org/10.1002/cdq.12030

Ardi, Z. (2012). Konseling Online: Sebuah Pendekatan Teknologi dalam Pelayanan Konseling. Seminar International Konseling MALINDO 2, 235-240.

Arsita, D. (2014). Potret Kehidupan Lesbian Kota Pekanbaru. Jom FISIP, 1(2), 1-15. http://doi.org/10.1017/CBO9781107415324.004

Azmi, K. R. (2015). Enam Kontinum dalam Konseling Transgender Sebagai Alternatif Solusi untuk Konseli LGBT. Jurnal Psikologi Pendidikan \& Konseling, 1, 50-57.

BBC News. (2015). Legalisasi Pernikahan Sejenis di AS Kuatkan Gerakan di Indonesia. Retrieved from www.bbc.com/150629_trensosisal_lgbt.html

Boellstorff, T. (2004). Gay Language and Indonesia: Registering Belonging. Journal of Linguistic Anthropology, 14(2), 248-268. http://doi.org/10.1525/jlin.2004.14.2.248

Dank, M., Lachman, P., Zweig, J. M., \& Yahner, J. (2014). Dating Violence Experiences of Lesbian, Gay, Bisexual, and Transgender Youth. Journal of Youth and Adolescence, 43(5), 846-857. http://doi.org/10.1007/s10964-013-9975-8

Davido, R. (2012). Mengenal Anak Melalui Gambar. Jakarta: Salemba Humanika.

Fifi, E. K. (2015). Perilaku Lesbian dalam Mempertahankan Pasangan di Tempat Kost di Kelurahan Pulai Anak Air Bukittinggi. Pendidikan Sosiologi STKIP PGRI Sumatera Barat, 1(10070226). http://doi.org/10.1017/CBO9781107415324.004

Gattis, M. N., Woodford, M. R., \& Han, Y. (2014). Discrimination and Depressive Symptoms Among Sexual Minority Youth: Is Gay-Affirming Religious Affiliation a Protective Factor? Archives of Sexual Behavior, 43(8), 1589-1599. http://doi.org/10.1007/s10508-014-0342-y

Juditha, C. (2014). Realitas lesbian, gay, biseksual, dan transgender (LGBT) dalam majalah. Jurnal Komunikasi Universitas Tarumanagara, 4(3), 22-30.

Kahija, Y. La. (2007). Hipnoterapi: Prinsip-prinsip Dasar Praktik Psikoterapi. Jakarta: Gramedia Pustaka Utama.

Kementerian Pendidikan Nasional. Undang-Undang Republik Indonesia Nomor 20 Tahun 2003 Tentang Sistem Pendidikan Nasional (2003). http://doi.org/10.1007/s13398-014-0173-7.2 
Mariani, O. (2013). Hubungan antara Dukungan Sosial dan Komitmen Beragama dengan Internalized Homophobia pada Lesbian. Jurnal Ilmiah Mahasiswa Universitas Surabaya, 2(2), 1-10.

Marjohan. (2012). Biografi Keilmuan Prayitno dalam Ranah Konseling dan Pendidikan. Padang: UNP Press.

Pontororing, M. (2012). Kaum Lesbian di Kota Manado. FISIP UNSRAT.

Rhomadona, S. W. (2012). Pengaruh Pengetahuan dan Sikap Tentang Kesehatan Reproduksi Terhadap Perilaku Kesehatan Wanita Lesbian di Kota Bandung. Sekolah Tinggi Ilmu Kesehatan William Booth Surabaya.

Richardson, H. B., Armstrong, J. L., Hines, D. A., \& Palm Reed, K. M. (2015). Sexual Violence and HelpSeeking Among LGBQ and Heterosexual College Students. Partner Abuse, 6(1), $29-46$. http://doi.org/http://dx.doi.org/10.1891/1946-6560.6.1.29

Rubin, J. A. (2010). Introduction to Art Therapy. New York: Routledge.

S.L., R., K., F., A., L., Ridner, S. L., Frost, K., \& LaJoie, A. S. (2006). Health information and risk behaviors among lesbian, gay, and bisexual college students. Journal of the American Academy of Nurse Practitioners, 18(8), 374-378. http://doi.org/10.1111/j.1745-7599.2006.00142.x

Saputra, M. N. (2015). Fenomena Komunikasi Mahasiswi Lesbian Label Butch di Kota Pekanbaru. JOM FISIP, 1(1), 1-11. http://doi.org/10.1017/CBO9781107415324.004

Siregar, C. (2013). Bisexual Profile In Pekanbaru City. Jom FISIP, 53(9), 1689-1699. http://doi.org/10.1017/CBO9781107415324.004

Sumadi, N., \& Wahyu, S. (2013). Pengalaman Traumatik dan Komunikasi Keluarga Efektif dalam Pembentukan Pribadi Penyimpangan Seksual Lesbian. Fakultas Kedokteran Universitas Tanjungpura Pontianak.

Vitasandy, T. D. (2010). Konsep diri pria biseksual. Jurnal Psikologi, 3(100), 188-194.

World Health Organizaton. (2001). The World Mental Health Report: New Understanding, New Hope. Geneva: World Health Organization.

Worthen, M. G. F. (2012). Understanding College Student Attitudes toward LGBT Individuals. Sociological Focus, 45(4), 285-305. http://doi.org/10.1080/00380237.2012.712857

Yuwono, W. (2013). Relationships Development Dalam Konteks Persahabatan Yang Dibangun Antara Perempuan Lesbian Dengan Perempuan Heteroseksual. JURNAL E-KOMUNIKASI, I(3). 